\title{
Addressing the Global Backlash against Investment Arbitration? A Multilateral Investment Agreement and China*
}

\author{
Junqing Chao ${ }^{* *}$
}

Over the past decade, the backlash against investment arbitration has become worldwide and correspondingly the investment treaty reform has been undertaken at multiple levels. In this context, a multilateral investment agreement ("MIA") has been called for as a global effort to address the global backlash. Arguably, the current condition for a MIA might be more favorable than before, as the interests of developed countries and developing countries have changed. After examining the need of a MIA for the global backlash, this paper attempts to explore China's recent practice in this aspect, including that (1) China's changing interest in outward foreign direct investment and investment treaty practice reflect the changing landscape of international investment law; (2) the 2016 G20 under China's presidency achieved the Guiding Principles for Global Investment Policymaking; and (3) China has joined to work on a multilateral framework on investment facilitation at the WTO.

Keywords: Global Backlash, Multilateral Investment Agreement, G20 Guiding Principles, Multilateral Framework on Investment Facilitation

* This article is fully revised and updated version of my paper (Is a Multilateral Investment Treaty Needed?) presented in the Conference organized by The World Trade Institute of the University of Bern (June 19, 2017) and the Asian Institute of International Financial Law of the University of Hong Kong (Oct. 20, 2017). All the websites cited in this article were last visited on August 7, 2019.

** Ph.D. candidate at Faculty of Law of The University of Hong Kong. LL.B. (ECUPL), LL.M. (Leeds). ORCID: https://orcid.org/0000-0002-7757-7866. I would like to thank my supervisor, Professor Chin Leng Lim, and Professor Manjiao Chi, Sheng Zhang, Peng Wang and Ji Ma for their valuable comments on an earlier draft of this article. All errors are my own. The author may be contacted at: junqingchao@hotmail.com/Address: Room 425, Cheng Yu Tung Tower, The University of Hong Kong, Pokfulam Road, Hong Kong. 


\section{INTRODUCTION}

The existing international investment regime is mainly built on a "spaghetti bowl' of over 3,322 international investment agreements ("IIAs"), 2946 of which are bilateral investment treaties ("BITs") and 376 of which are treaties with investment provisions ("TIPs"). ${ }^{1}$ No multilateral agreement exists to regulate foreign investment, even though many attempts were made in history. In recent, there has been a shift from bilateral investment treaties ("BITs") to regional IIAs, which, to some extent, is a reaction to those failed multilateral attempts. ${ }^{2}$ Such an international investment regime, since the early 2000s, has experienced a 'legitimacy crisis.' ${ }^{3}$ In particular, investment arbitration has generated widespread criticism, from not only academic writings and NGOs, but also more importantly governments. A significant number of countries, ranging from the United States ("US"), Canada and Mexico to Bolivia, Ecuador, Venezuela, South Africa, Indonesia, and Australia, have expressed their discontent with investment arbitration. The backlash against investment arbitration has become worldwide. ${ }^{4}$

As a response, many countries have formulated and refined their investment treaties, such as the 2012 US Model BIT and 2015 Indian Model BIT. ${ }^{5}$ The European Union ("EU") has also been working on its investment approach under its agreement negotiations. Furthermore, the investment treaty reform has also been undertaken at the bilateral, regional and multilateral levels. However, the current multilateral reform effort is deemed insufficient, as it has mainly focused on the procedural aspect. ${ }^{6}$ Therefore, some commentators and international organizations have called for a multilateral investment agreement ("MIA") in recent, arguying that the current condition is ripe mainly due to the changing interests of developing and developed countries. ${ }^{7}$ On this point, divergent views have also been expressed, ${ }^{8}$ but overall we are seeing the revival of the interest in establishing multilateral investment rules under the global backlash.

For China, its outward FDI has dramatically increased over the past decade and its role in international investment law has changed from merely a capital importer to both a capital importer as well as exporter. In 2017, China was the second largest capital importer and meanwhile the third largest capital exporter, with 136 and 126 billion of dollars of inward and outward FDI, respectively. ${ }^{9}$ This change has a crucial bearing on China's investment treaty practice. The 
case of China might be able to serve as an example for the changing landscape of international investment law. Moreover, China has participated in the conclusion of the Guiding Principles for Global Investment Policymaking at the 2016 G20 and the establishment of a multilateral framework on investment facilitation at the WTO.

This research attempts to examine the global backlash against investment arbitration from the perspective of the need of a MIA and explore China's recent practice in this aspect. This paper is composed of seven parts including Introduction and Conclusion. Part two will review the failed multilateral investment agreement attempts in the history. After examining the global backlash and the investment treaty reform, Part three will discuss the need of a MIA for the global backlash. Part four will then examine China's changing interest in outward FDI and investment treaty practice. Parts five and six will explore China's practice in the Guiding Principles for Global Investment Policymaking achieved at the 2016 G20 and the multilateral framework on investment facilitation promoted at the WTO.

\section{Multilateralism in Investment Treaty-Making}

Early in 1948, an attempt was made in the Havana Charter to establish a multilateral investment agreement. Article 12 of the Havana Charter addressed international investment for economic development and reconstruction, stating that: "Members also undertake, upon request, to participate in negotiations for bilateral and multilateral agreements on the subject of investment." ${ }^{, 10}$ But the Havana Charter finally did not enter into force. During the 1970s, the debate over the regulation of foreign investment took place at the United Nations ("UN"), as reflected in the 1974 Declaration on the Establishment of a New International Economic Order and in the 1974 Charter of Economic Rights and Duties of States. ${ }^{11}$ As a result, negotiations were started for the UN Code of Conduct on Transnational Corporations. At that time, developed countries were the main sources of foreign investment and naturally wished to maximize investment protection, while developing countries, as the recipients of foreign investment, focused on their regulatory space to pursue public policy objectives. ${ }^{12}$ The challenge thus was to bridge these different interests and find a right balance between the 
rights and obligations of transnational corporations and the host state. ${ }^{13}$ It turned out that this challenge was huge and the negotiation ended in 1993.

For the UN Code of Conduct on Transnational Corporations, it was argued that the real negotiation indeed lasted till the early 1980s and one of the reasons for its failure was the conclusion of BITs during that period. ${ }^{14}$ The BITs usually focused on the protection of foreign investment and the establishment of an effective dispute settlement mechanism, which were in the interest of developed countries. Although the first BIT was concluded in 1959 between Germany and Pakistan, there were 381 BITs by the end of 1980s. ${ }^{15}$ An increasing number of BITs offered effective protection for foreign investment and later even promoted investment liberalization. ${ }^{16}$ Subsequently, the 1990s witnessed the dominance of neo-liberalism and the proliferation of BITs. Developing countries concluded a large number of BITs with developed countries to compete for foreign capitals. The number of BITs reached 2067 by the end of 2000. ${ }^{17}$ During this period, another attempt was launched at the Organization for Economic Co-operation and Development ("OECD") to establish a multilateral agreement on investment ("MAI").

The negotiation on the MAI began in 1995. The idea was to draft an investment agreement among the OECD countries and then allow developing countries to accede to the agreement. ${ }^{18}$ The MAI, based on the existing BITs, aimed for the "high standards for the liberalization of investment regimes and investment protection" and the "effective dispute settlement procedures." It was believed that the time was ripe and the negotiation was just a "technical process. ${ }^{, 20}$ However, the Draft MAI, once released, provoked widespread criticism. After the withdrawal of France in 1998, the OECD had to discontinue the MAI negotiation. Subsequently, the venue for establishing multilateral investment rules was moved to the World Trade Organization ("WTO").

Many attributed the failure of the OECD MAI to the opposition of the NGOs. ${ }^{22}$ The NGOs criticized the increase of investor rights and were concerned about the environmental and labor issues. ${ }^{23}$ The underlying issue, as Kobrin pointed out, was "a general anxiety about globalization" and what followed the failed OECD MAI were Seattle WTO protests in 1999. ${ }^{24}$ Another opposition came from some developing countries, notably India, Pakistan and Malaysia, for their exclusion from the MAI negotiation. ${ }^{25}$ Except for the political context, it cannot be ignored 
that the OECD countries themselves could not reach a consensus on many substantive issues, such as national treatment, performance requirement, indirect expropriation, environmental and labor issues, cultural exception and investorstate dispute settlement ("ISDS"). ${ }^{26}$ The United Nations Conference for Trade and Development ("UNCTAD") noted that the difficult issues for the MAI negotiation "touched upon a whole range of domestic concerns" and that a certain degree of flexibility should be given to the host states to pursue their own national policy objectives. $^{27}$

At the WTO, investment, as one of the 'Singapore Issues,' was not successfully included in the Doha Round agenda at the Cancun Ministerial Conference in $2003 .^{28}$ The failure at the WTO was mainly attributed to the conflict of interests between developed and developing countries. ${ }^{29}$ It was revealed that the EU, Japan and Korea promoted to include all four Singapore issues, but this was opposed by many developing countries. ${ }^{30}$ The US was more interested in market access rather than generalized principles. ${ }^{31}$ The challenge returned to the North-South divide. Interestingly, in the next year, the US and Canada released their 2004 Model BITs with an aim to rebalance the interests of foreign investors and the host states. ${ }^{32}$ The rebalancing practice was subsequently undertaken by an increasing number of countries under the global backlash against investment arbitration.

\section{Global Backlash and Investment Treaty Reform}

The 2004 US Model BIT and the 2004 Canadian Model BIT were a result of the North American Free Trade Agreement ("NAFTA") backlash against investment arbitration. Since the late 1990s, three NAFTA states were increasingly discontent with the expansive interpretations of investment provisions by tribunals, and in July 2001 issued an Interpretation Note to clarify and reaffirm the meanings of some provisions. ${ }^{33}$ In particular, an international rule was set as a roof for fair and equitable treatment ("FET") and full protection and security ("FPS"). ${ }^{34}$ This clarification responded to awards like Pope \& Talbot v. Canada, where the tribunal interpreted the FET standard as "additive to the requirements of international law. ${ }^{, 35}$ It was also clarified that a violation of other NAFTA obligations could not constitute a violation of the FET obligation, in response to awards like $S$. D. Myers 
v. Canada, where the tribunal determined that the breach of the national treatment provision "essentially establishes a breach of Article 1105" [minimum standard of treatment $].{ }^{36}$ Furthermore, the Interpretation Note reaffirmed that nothing in the NAFTA prevented parties from "providing public access to documents submitted to, or issued by" a tribunal, ${ }^{37}$ for the public concern over the transparency of arbitral proceedings. ${ }^{38}$

The Interpretation Note had a great impact on the formulation of the 2004 US Model BIT. The clarifications on the FET and FPS discussed above were copied by the minimum standard of treatment provision of the 2004 US Model BIT. Furthermore, the 2004 US Model BIT not only clarified other substantive issues, such as indirect expropriation, but also improved the ISDS process, including arbitral transparency. ${ }^{39}$ For indirect expropriation, an Annex was included for its definition, determination as well as exception. ${ }^{40}$ It stated: "Except in rare circumstances, non-discriminatory regulatory actions by a Party that are designed and applied to protect legitimate public welfare objectives, such as public health, safety, and the environment, do not constitute indirect expropriation." ${ }^{41}$ It is also worth mentioning that some social concerns raised by the NGOs were addressed. The 2004 US Model BIT required that the host state should not lower the environmental and labor standards to attract foreign investment. ${ }^{42}$

Notwithstanding, the backlash against investment arbitration spread all over the world. In 2007, Bolivia denounced the International Center for the Settlement of Investment Disputes (“ICSID”) Convention, followed by Ecuador in 2010 and Venezuela in 2012. South Africa and Indonesia decided to terminate their investment treaties in 2012 and 2014 respectively. South Africa's decision was based on its three-year BIT review. ${ }^{43}$ Indonesia's termination practice was mainly attributed to the Churchill Mining v. Indonesia. ${ }^{44}$ In 2010, Australia joined the backlash declining to include investor-state dispute settlement provisions in the future investment treaties. ${ }^{45}$ This was perhaps due to the Philip Morris v. Australia in which Australia's Tobacco Plain Package Act was challenged. ${ }^{46}$

The criticisms over investment arbitration are focused on both substantive and procedural aspects. It is argued, for example, that: arbitral tribunals still enjoy too much discretion in interpreting investment treaties; ${ }^{47}$ there is a systematic bias in favor of foreign investors, ${ }^{48}$ investment treaties lack provisions governing the obligations of foreign investments; ${ }^{49}$ the ad hoc tribunal system leads to 
inconsistent law; ${ }^{50}$ there is a conflict of interests among arbitrators; ${ }^{51}$ and so forth. Some studies even doubt whether the conclusion of investment treaties plays a role in attracting foreign investment. ${ }^{52}$ More importantly, it has been questioned whether the current investment treaty and arbitration regime constrains the regulatory space of the host state, especially after the Argentinian crisis and the 2008 financial crisis. ${ }^{53}$

Under the global backlash, except for the radical reactions, many countries have chosen to reformulate their investment treaties and rebalance the protection of foreign investment and the right of states to regulate. The US initialed another round of BIT review in 2009 and then released a new 2012 Model BIT. ${ }^{54}$ The EU has formulated the investment approach under its agreement negotiations with other countries and has recently proposed an investment court to replace investorstate arbitration. ${ }^{55}$ In 2015, India released a new Model BIT with many changes responding to the specific investment arbitrations India experienced, such as White Industries $v$ India. ${ }^{56}$ China was not involved in investment arbitration until 2007, but an earlier attempt to clarify indirect expropriation could be found in the 2006 China-India BIT. ${ }^{57}$ In the rebalancing practice, Chinese BITs have learned much from the US treaty practice. The refinement of Model BITs is considered by the UNCTAD as the national level of the investment treaty reform. ${ }^{58}$ In fact, the whole treaty reform has been undertaken at multiple levels.

At the bilateral and regional levels, countries have been involved in a number of agreement negotiations, in particular three mega-regional agreement negotiations of the Comprehensive and Progressive Agreement for Trans-Pacific Partnership ("CPTPP"), the Transatlantic Trade and Investment Partnership ("TTIP"), and the Regional Comprehensive Economic Partnership ("RCEP"). The bilateral and regional agreement negotiations could provide countries with an opportunity to review the reform jointly and collectively. ${ }^{59}$ The UNCTAD noted that, despite the overlap and inconsistency, these regional agreements could undertake "more efficient and widespread reform" and even "harmonize and consolidate existing investment rules." ${ }^{, 60}$ Some, for example, believed that the CPTPP and the RCEP had the potential to lead to the harmonization of investment rules in the Asia-Pacific region. ${ }^{61}$ Additionally, both Latin America and Africa have prepared their regional centers for the settlement of investment disputes. ${ }^{62}$

As to the bilateral and regional investment agreements, Sauvant and Ortino 
argued that they could not address the challenges of international investment regime. ${ }^{63}$ The backlash against investment arbitration is a global phenomenon, which needs to be addressed at multilateral and plurilateral levels. ${ }^{64}$ However, the current multilateral reform effort has mainly concentrated on the investor-state dispute settlement. For example, the 2014 UNCITRAL Rules on Transparency in Treaty-based Investor-State Arbitration could address the arbitral transparency. ${ }^{65}$ The ICSID has also modernized its rules and regulations. Furthermore, the EU has recently proposed a multilateral investment court project and Canada and Vietnam have already joined the project. Despite these progresses, more work may need to be undertaken at the multilateral level.

In fact, many commentators and international organizations have called for a multilateral investment agreement in recent. ${ }^{66}$ They argued that the current condition for the establishment of multilateral investment rules may be more favorable than before, mainly because the landscape of international investment has changed. ${ }^{67}$ In 2003, when the investment was dropped from the Doha Round agenda, the outward FDI from developing countries only accounted for less than 10 percent of the world outward FDI flows. ${ }^{68}$ However, in 2017, around one third of the world outward FDI flows was from developing countries. ${ }^{69}$ This means that developing countries now may tend to view IIAs from a capital exporter perspective. At the same time, developed countries have started to consider their interests as a capital importer. ${ }^{70}$ The 2004 US Model BIT is an example in point. The changing interests of both developing and developed countries may be able to deal with the traditional North-South conflict. ${ }^{71}$

Apart from the potential convergence of interests, a large number of investment agreement negotiations, especially the mega-regional agreement negotiations, could serve as a basis for the negotiations on a multilateral investment agreement. ${ }^{72}$ It was even argued that some important agreements could lead to the convergence of investment rules, with four features of promoting investment liberalization, clarifying investment protection provisions, and improving the investor-state dispute settlement including some social provisions. ${ }^{73}$ Thirdly, the multilateral investment court proposed by the EU could help to advance the multilateral reform. ${ }^{74}$ The EU did not mention a multilateral investment agreement in the court project, but the multilateral investment court, as the UNCTAD noted, could benefit from multilateral investment rules. ${ }^{75}$ Despite these favorable conditions, it has 
been questioned whether a multilateral investment agreement was able to address the global backlash against investment arbitration and whether a multilateral investment agreement was desirable and feasible in the real world. ${ }^{76}$

Many have argued that the WTO is a desirable platform for creating a multilateral investment agreement, especially given the close link between trade and investment. ${ }^{77}$ But they also have admitted that it may be different for the WTO members to start a negotiation on multilateral investment rules at present. ${ }^{78}$ The Doha Round has been processed slowly and the WTO members have turned to their bilateral and regional agreement negotiations. Therefore, it has been suggested that "an MIA would have to be a plurilateral agreement within the framework of the WTO and not a universal one." ${ }^{, 79}$ At the WTO, a plurilateral investment agreement could be undertaken in a manner similar to the Trade in Services Agreement. ${ }^{80}$ Alternatively, the discussion could be launched at the plurilateral level, such as the G20, to "assess the desirability and feasibility" of a plurilateral investment agreement and "go further and give overall political guidance." ${ }^{, 81}$ Other suggested platforms include the UNCTAD, the OECD, the UN, World Bank, the Asia-Pacific Economic Cooperation and the Asian Infrastructure Investment Bank. ${ }^{82}$

In sum, the investment treaty reform has revived the public interest in establishing multilateral investment rules. A multilateral investment agreement has been called for as a global effort for addressing the global backlash. The NorthSouth conflict, which mainly contributed to the failed multilateral attempts, could be addressed by the changing interests of developed and developing countries. In fact, the changing landscape of international law could be reflected by China's changing interest in outward FDI and investment treaty practice, which will be examined in detail below.

\section{China's Investment Treaty Practice}

Following the adoption of the 'Open Door' policy, China signed its first BIT in 1982 with Sweden. ${ }^{83}$ The launch of the BIT program aimed at offering an international legal insurance to attract foreign investors to invest in China. ${ }^{84}$ Therefore, China's first and second generation BITs, concluded from 1982 to 
1997, were drafted from a capital importer perspective and presented a conservative approach. ${ }^{85}$ For example, a restrictive investor-state dispute settlement provision was included only allowing that "a dispute involving the amount of the compensation for expropriation" could be submitted to international arbitration. ${ }^{86}$ Such a provision has been interpreted differently in investment arbitration jurisprudence. A narrow reading allows tribunals to determine the disputes involving the amount of compensation for expropriation, while, under a broad reading, not only the amount issue, but also other issues related to expropriation could be determined. ${ }^{87}$ Two readings have both been adopted in China's investment arbitration practice. ${ }^{88}$

Furthermore, under the first and second generations, no national treatment or only 'best endeavor' national treatment was provided to foreign investors. ${ }^{89}$ This could be attributed to China's regulatory framework for FDI. Three laws, including the Sino-Foreign Equity Joint Venture Law, the Sino-Foreign Contractual Joint Venture Law, and the Wholly Foreign Owned Enterprises Law, were established for three forms of foreign invested enterprises. ${ }^{90}$ Foreign investments were also guided by the Catalogue for the Guidance of Foreign Investment Industries (hereinafter Catalogue) under three categories of 'encouraged,' 'restricted,' and 'prohibited. ${ }^{91}$ It is worth mentioning that during this period the Code of Conduct on Transnational Corporation was negotiated at the UN. Sauvant observed that China "maintained a low profile" in the negotiations.

From 1998, Chinese BITs changed its approach from 'conservative' to 'liberal,' thereby entering into the third generation. One of the biggest changes was that all kinds of investment disputes could be submitted to international arbitration under the third generation. ${ }^{93}$ Although foreign investors were required to "go through the domestic administrative review procedures" before international arbitration, but this requirement would not prevent foreign investors from the access to international arbitration. ${ }^{94}$ Furthermore, a qualified national treatment, subject to local laws and regulations or to non-conforming measures, was also provided, but was only limited to the post-establishment stage. ${ }^{95}$ Foreign investments needed to be approved by the Chinese government on a case-by-case basis. But China's FDI regime was liberalized and the numbers of the restricted and prohibited measures in the Catalogue were decreased. ${ }^{96}$ Overall, China's third generation BITs were regarded as conforming to "what can be considered as standard treaty practice in approximately 2500 BITs worldwide" in all major aspects. ${ }^{97}$ 
Many commentators attributed China's changing BIT approach to its outward FDI. ${ }^{98}$ In 1998, the Chinese government adopted a 'Go Abroad' policy to encourage Chinese companies to invest in foreign countries. The protection of overseas investment thus became a consideration for Chinese BITs. However, the rationale for this changing approach should not be limited to this. At the time, China was still in the need of foreign investment. As stated above, during the 1990s, many developing countries concluded a large number of BITs to compete for foreign capitals. China did not wish to lag behind and "felt urge to further liberalize the regime." 99 The focus of China's FDI policy had been changed from quantity to quality until $2006 .^{100}$

The year 1998 witnessed the release of the OECD MAI draft. As discussed above, the MAI draft generated criticism from the NGOs for the social concerns and from developing countries for the exclusion of negotiations. China participated in the MAI negotiation as an observer. After analyzing the MAI draft, Chinese scholars argued that the investment liberalization and protection standards in the MAI were too high for China. ${ }^{101}$ Subsequently, when investment was discussed at the WTO, there was a heated debate among Chinese scholars as to whether China should support the establishment of a multilateral investment agreement. Opponents argued that there was no need of a MAI for China, because China did not mainly rely on the BITs to attract foreign investment. ${ }^{102}$ The WTO investment attempt, as discussed above, failed mainly due to the North-South conflict. Afterwards, the EU proposed a plurilateral approach towards investment. ${ }^{103}$ This proposal gained support from the US, Japan and Korea, but was opposed by Canada, New Zealand and many developing countries including China. ${ }^{104}$

However, China's outward FDI has increased sixfold over the past decade, from USD 18 billions (2007) to USD 124 billions (2017). ${ }^{105}$ Meanwhile, China's inward FDI has experienced a tremendous increase from USD 76 billions to USD 136 billions during this period of time. ${ }^{106}$ As discussed above, China now has become both a capital importer and exporter. China's outward FDI is expected to grow in the next years in the light of the "One Belt One Road" initiative. In fact, in 2016, China became a net capital exporter, with USD 134 billion and USD 196 billion inward and outward FDI, respectively. ${ }^{107}$ China's changing role in international investment has had a crucial bearing on its investment treaty practice.

In 2013, China accepted pre-establishment national treatment and a negative 
list approach under its BIT negotiation with the US. ${ }^{108}$ Subsequently the Shanghai Free Trade Zone ("FTZ") was established to test how to reform China's trade and investment laws for future treaty negotiations. ${ }^{109}$ In recent years, the Shanghai FTZ has simplified the approval procedures for foreign investment and published several versions of the negative list. More importantly, in 2019, a new foreign investment law was approved by the Chinese government for "the convergence of China's foreign and domestic investment regimes." ${ }^{110}$ Article 4 of the new Foreign Investment Law provides that foreign investors should be granted preestablishment national treatment on the basis of a negative list approach. ${ }^{111}$ In the 2017 version of the Catalogue, the encouraged industries with shareholding requirements, the restricted industries and the prohibited industries were converged into one category named Special Administrative Measures for the Entry of Foreign Investment (Negative List). ${ }^{112}$ The number of special administrative measures was reduced from 63 to 48 in the 2018 version of the Catalogue. ${ }^{113}$

In addition, Chinese investment treaties have been progressively rebalanced over the past decade. It has been observed that China's rebalancing practice has learned from the US practice, especially the 2004 US Model BIT. ${ }^{114}$ More specifically, the FET and FPS are referred to customary international law or international law and several of the FET and FPS elements are listed as examples: ${ }^{.15}$ the definition and determination of indirect expropriation are clarified and an expropriation exception is included for legitimate public policy objectives; ${ }^{116}$ several exception clauses are also included for preserving the regulatory space of the host state in terms of essential security, environment, tax, financial affairs, information and culture; ${ }^{117}$ and the investor-state dispute settlement mechanism is improved. ${ }^{118}$ The arbitral transparency would be a problem for China, as it has only accepted to publish the arbitral awards in its investment treaties. ${ }^{119}$

Judging from above, it seems that Chinese BITs will be entering into the fourth generation. ${ }^{120}$ It is likely that the fourth generation of Chinese BITs will provide pre-establishment national treatment on the basis of a negative list approach and rebalance the protection of foreign investment and the right of states to regulate. The emergence of the fourth generation is mainly due to the increase of China's outward FDI. ${ }^{121}$ Other factors include China's domestic reform and the rebalancing debate in international investment law. ${ }^{122}$ Against this background, the issue of China and a multilateral investment agreement has started to attract 
public attention. It was explored whether the China-US BIT and China-EU BIT could have any implications for multilateral investment treaty making. ${ }^{123}$ It was also suggested that China should launch the discussions on multilateral investment rules at the $2016 \mathrm{G} 20{ }^{124}$

In sum, China's outward FDI interest and BIT practice have profoundly changed over the past decades, which could serve as an example for the changing landscape of international investment law. During this process, the issue of China and multilateral investment agreement has been a subject of debate. More importantly, in recent, China has participated in the promotion and establishment of multilateral investment rules at the G20 and the WTO. China's recent practice will be examined below.

\section{G20 Guiding Principles for Global Investment Policymaking}

In 2016, China took the presidency of the G20 Summit and established a Trade and Investment Working Group. The Working Group was designed to discuss the implementation of the trade and investment commitments, the cooperation on trade and investment as well as other related issues. ${ }^{125}$ In 2016, the Working Group was co-chaired by China and Canada with the support of other BRICS countries and the international organizations, especially the UNCTAD. ${ }^{126}$ After more than ten rounds of negotiation, the G20 trade ministers agreed on the Guiding Principles for Global Investment Policymaking (hereinafter G20 Guiding Principles) in July 2016, which were endorsed by the G20 leaders at Hangzhou Summit in September $2016 .^{127}$

The non-binding Guiding Principles have three main objectives: (1) the creation of an open, transparent and conductive global investment policy environment; (2) the promotion of the coherence in national and international investment policymaking; and (3) the promotion of inclusive economic growth and sustainable development. ${ }^{128}$ The following issues are addressed: (1) the avoidance of investment protectionism; (2) the protection of investment, the transparency and coherence in investment rule making; (3) the right to regulate for legitimate public policy purposes, the promotion and facilitation of investment, responsible 
business conduct; (4) and international cooperation on investment. ${ }^{129}$ Overall, four areas of investment are all covered: investment liberalization; investment promotion and facilitation; investment protection and dispute settlement. ${ }^{130}$ The G20 Guiding Principles is considered to be a landmark as the first consensus on global investment policymaking achieved among the various countries. ${ }^{131}$

However, some commentators have noticed that several principles are too general and do not go into specific issues. For example, Principle III states: ${ }^{132}$

Investment policies should provide legal certainty and strong protection to investors and investments, tangible and intangible, including access to effective mechanisms for the prevention and settlement of disputes, as well as to enforcement procedures. Dispute settlement procedures should be fair, open and transparent, with appropriate safeguards to prevent abuse.

It can be seen that, except for the asset-based definition of investment, this principle does not go into other protection issues, such as national treatment, mostfavored-nation treatment and FET. ${ }^{133}$ This is also the case for dispute settlement. This principle emphasizes fair, open and transparent dispute settlement procedures, but does not address specific procedural rules and the type of dispute settlement mechanism. ${ }^{134}$ These 'silences,' in Zhan's view, reflect that the G20 countries could not reach a consensus on specific investment treaty provisions. ${ }^{135}$

On this point, a closer examination of the treaty practices of the G20 countries suggests that these countries, at least some of them, have different views as to the specific investment protection provisions. The clarification on the FET and FPS is a good example in point. More specifically, the US Model BIT, learning from the NAFTA experience, sets customary international law as the roof for the FET and FPS and includes an open list of the FET and FPS elements. ${ }^{136}$ The listed elements could not prevent tribunals from turning to other elements developed in investment arbitrations. ${ }^{137}$ The US clarifications on the FET and FPS have been learned by recent Chinese investment treaties, though they are included in different treaties. ${ }^{138}$ In contrast, a closed-list approach has been recently adopted by the EU and India. In the CETA, for example, several elements of the FET are listed for the tribunals' consideration. ${ }^{139}$ The closes-list approach is said to respond to the growing expansive interpretations of the FET standard and aim to further enhance the control on tribunals. ${ }^{140}$ 
As to the investor-state dispute settlement, the US Model BITs have sought to fix the existing ISDS mechanism, including the regulation of arbitrators, the consolidation of relevant claims, the transparency of arbitral proceedings and the establishment of appellate mechanism. ${ }^{141}$ Roberts regarded the US as the loyalist to the ISDS reform. ${ }^{142}$ The EU, as a reformist, has recently proposed a multilateral investment court to replace investor-state arbitration. ${ }^{143}$ Judging from the treaty practice, China and India have worked on the improvement of the existing ISDS mechanism, but they, as Roberts argued, might be viewed as the undecided states under the reform. ${ }^{144}$ For India, its Model BIT imposes strict conditions on access to international arbitration. ${ }^{145}$ It remains to be seen whether China would join the multilateral investment court under its BIT negotiation with the EU. Apart form these practices, Brazil has promoted a dispute prevention mechanism, ${ }^{146}$ while South Africa now tends to employ domestic medication for resolving the investorstate disputes. ${ }^{147}$ Given the continuing debate over the ISDS, the UNCITRAL has established a Working Group for the ISDS reform, seeking to identify the concerns over the ISDS and develop relevant solutions.

Another example for the general language is Principle VI, in which governments reaffirm their right to regulate investment for legitimate public policy purposes. ${ }^{148}$ This reaffirmation corresponds to the investment treaty reform under the global backlash. In practice, some G20 countries have already included this reaffirmation in the preambles of their Model BITs. For example, the 2012 US Model BIT addresses the consistency of investment protection with other public policy objectives, including the protection of health, safety, and environment and the promotion of labor rights. ${ }^{149}$ The preamble of the 2015 Indian Model BIT reaffirms "the right of parties to regulate investments in their territory in accordance with their law and policy objectives." includes a separate provision to address investment and regulate measures. After reaffirming the right to regulate to achieve legitimate public policy objectives, Article 8.9 of the CETA clarifies what does not constitute a breach of an obligation with respect to the modification of laws and the issue of renewal and maintenance of a subsidy. ${ }^{151}$ On this principle, it was revealed that the G20 countries tried to offer some examples for the legitimate public policy purposes but failed. ${ }^{152} \mathrm{In}$ practice, the CETA and the 2012 Canada-China BIT go beyond the protection of safety, health and environment to protect cultural industries. ${ }^{153}$ 
The general language of the Guiding Principles reflects that the G20 countries have different interests in, or could not reach a consensus on, many specific investment issues. It was revealed that, during the negotiation, developed countries, notably the US, were more interested in investing abroad, high-standard investment liberalization, market access, non-discrimination and transparency. ${ }^{154}$ In contrast, emerging economies, including India, Brazil and South Africa, focused more on attracting foreign investment, industrial security and development, and the regulatory space of the host state. ${ }^{155}$ The EU and China both sought for a balance between the protection and liberalization of foreign investment, and the right of states to regulate. ${ }^{156}$ Indeed, it was the general language that made the G20 Guiding Principles possible. ${ }^{157}$ The specific investment issues could not be agreed at this stage.

Overall, the G20 Guiding Principles could serve as a stepping stone towards the eventual establishment of multilateral investment rules. ${ }^{158}$ However, the general language of the Guiding Principles suggests that the G20 countries still had divergent interests in some specific investment issues. In this case, countries may need to turn to bilateral or regional agreements for a convergence. Sauvant observed that now key governments might not be interested in a multilateral investment framework, but wished to address their bilateral and regional agreement negotiations first. ${ }^{159}$ In fact, the bilateral and regional agreements, as discussed above, could form a basis for the multilateral negotiations on investment rules.

In addition, some found that investment facilitation was less controversial than other three issues of investment liberalization, investment protection, and dispute settlement with the potential to be advanced. ${ }^{160}$ At the 2016 G20, a draft framework on investment facilitation, prepared by the UNCTAD, was submitted to the Trade and Investment Working Group. ${ }^{161}$ However, due to the lack of time, no concrete outcome was achieved in the end. The G20 trade ministers in their statement agreed to take actions to promote and facilitate international investment. ${ }^{162}$ Subsequently in the 2017 G20, Germany aimed for an investment facilitation package, which was, however, opposed by India, South Africa and the US. ${ }^{163}$ Fortunately, the discussion on investment facilitation was successfully advanced at the WTO. 


\section{Moving Investment Facilitation Forward AT THE WTO}

Investment facilitation has started to attract public attention, especially after the adoption of the WTO Trade Facilitation Agreement. The UNCTAD, the OECD and the APEC have undertaken much work on this issue. ${ }^{164}$ A multilateral framework or an international support program for investment facilitation, as argued, could increase the FDI flows, especially those from high-income countries to developing countries. ${ }^{165}$ But there is no consensus of the definition and content of investment facilitation, so that the concept of investment facilitation is always confused with that of investment promotion. ${ }^{166}$ As stated above, the 2016 G20 and the 2017 G20 both launched the discussions on investment facilitation, but in the end no concrete outcome was achieved, due to the lack of time or the opposition of some countries. Subsequently, the discussion on investment facilitation was moved to the WTO.

In April 2017, several countries, including Argentina, Brazil, China, Colombia, Hong Kong, Mexico, Nigeria and Pakistan (the Friends of Investment Facilitation for Development: "FIFD") established an informal dialogue on investment facilitation for development at the WTO. ${ }^{167}$ This dialogue aimed at discussing the link between trade and investment, examining the existing good practices of the members concerning investment facilitation, as well as exploring the role of the WTO in advancing the investment facilitation discussions. ${ }^{168}$ At the same time, several proposals were submitted by Russia, China, Brazil and Argentina respectively concerning the possible elements of investment facilitation for the WTO members' consideration. ${ }^{169}$

As discussed above, investment was once included as one of the 'Singapore issues' for the Doha Round, but was finally dropped from the agenda at the 2003 Cancun Ministerial Conference. Many contributed this failure to the opposition of developing countries who argued that investment was beyond the scope of the WTO negotiations. ${ }^{170}$ However, today, developing countries propose the investment facilitation dialogue at the WTO. One of the concerns remains that investment is not part of the WTO negotiation agenda, but today the close linkage between trade and investment is being increasingly recognized. ${ }^{171}$ The opponents have also argued that an investment facilitation framework would constrain the 
countries' ability to regulate investment and even questioned the actual benefit developing countries could get from the framework. ${ }^{172}$

One may wonder why these developing countries propose an investment dialogue presently. ${ }^{173}$ First, it has been recognized among these countries that investment has a close linkage with trade, especially under the global value chain. ${ }^{174}$ At the joint communication from the FIFD, it was stated that the proposal of the dialogue was based on the consideration of "the increasing the interlinkage between trade and investment, their mutually reinforcing role in fostering global development and inclusive income and the growing interest in this area in the WTO." ${ }^{175}$ Second, these developing countries have become the top among important capital exporters. In 2017, China, Hong Kong, and Russia were the third, fifth and eleventh largest capital exporters. ${ }^{176}$ A multilateral regime for investment facilitation would be in the interest of these countries. ${ }^{177}$ Third, these developing countries still need the FDI for economic development. According to the UNCTAD, developing countries are in the need of the FDI of USD 2.5 trillion for the 2030 sustainable goal. ${ }^{178}$ The Chinese delegation, Zhang Xiangchen, in his speech held that for the purpose of attracting FDI, except for opening the market, countries could also promote investment facilitation. ${ }^{179}$ He added that investment facilitation, different from investment liberalization, investment promotion and investment protection, did not seek to change the level of liberalization, but instead improve the attractiveness of the existing open areas for foreign investment. ${ }^{180}$

In December 2017, the informal dialogue on investment facilitation was tabled at the 11th WTO Ministerial Conference. Eventually 70 countries (41 countries and the EU) agreed on a joint ministerial statement on investment facilitation for development in which they called for "beginning structured discussions with an aim of developing a multilateral framework on investment facilitation." ${ }^{181}$ As a response, Brazil submitted a draft investment facilitation agreement in January 2018. ${ }^{182}$ Subsequently in March 2018, the first constructed discussion on investment facilitation was launched at Geneva. It was reported that India was rethinking its position on the investment facilitation issue. ${ }^{183}$

In the joint ministerial statement on investment facilitation for development, it was reaffirmed that the discussions should not deal with the issues of market access, investment protection, and investor-state dispute settlement. ${ }^{184}$ It is further agreed that the framework should include the right of states to regulate for public 
policy objectives. ${ }^{185}$ This should be able to address one of the concerns mentioned above. Moreover, three elements of the framework are listed for the discussion, including (1) improving "the transparency, predictability of investment measures"; (2) streamlining and speeding up "administrative procedures and requirements"; and (3) enhancing "international cooperation, information sharing, the exchange of best practices, and relations with relevant stakeholders, including dispute prevention." ${ }^{, 186}$ The listed three elements are addressed in the proposals submitted by Russia, China, Argentina and Brazil. In this regard, Brazil's draft investment facilitation agreement below China's proposal will be examined to explore how China views these three elements of investment facilitation with other countries' proposals and draft agreement considered.

As for the transparency of investment measures, China's proposal addresses two issues: the publication of laws and regulations and the comment on proposed laws and regulations. Specifically, it is firstly stated that the laws and regulations related to investment should be made available to the public and the enquiry points should be established to respond to the enquiry about these laws and regulations. ${ }^{187}$ Secondly, to a possible extent, opportunities should be provided to comment on the drafts or amendments of the laws and regulations related to investment. ${ }^{188}$ These two issues are also addressed in the proposal of Argentina and Brazil and Brazil's draft agreement. ${ }^{199}$ It is worth mentioning that the comment opportunities are not addressed in the IIAs until recently, especially in the US Model BITs. ${ }^{190}$ The existing Chinese investment treaties do not address the comment opportunities, but the Shanghai FTZ has worked on this issue for the China-US BIT negotiation. ${ }^{191}$

When it comes to the efficiency of administrative procedures, China's proposal provides that the licensing and qualifications requirements and procedures relating to investment should be streamlined. ${ }^{192}$ If the application is incomplete, not only opportunities should be given to supply the information, but also the additional information should be specified. ${ }^{193}$ It is further suggested that the institutional cooperation and coordination among domestic regulatory authorities should be fostered, including establishing "a one-stop approval institution." 194 On this point, Russia, Brazil and Argentina proposed a single electronic window. ${ }^{195}$ Brazil's draft agreement specified that the single electronic window would serve as "a single entry point for the submission of all documents required" concerning the investment activities of the admission, establishment, acquisition and expansion. ${ }^{196}$ 
Except in rare cases, these documents should not be subsequently required "by any agency or regulatory body by other means." ${ }^{197}$

Thirdly, these proposals and the draft agreement almost all address the special and differential treatment for developing and least-developed countries and the investors' corporate social responsibilities. ${ }^{198}$ In recent, responsible business practice has started to be addressed in the IIAs, which was consolidated by the G20 Guiding Principles. Principle VIII takes a soft approach referring the corporate social responsibilities to "international best practices and applicable instruments of responsible business conduct and corporate governance." ${ }^{, 199}$ As to the treaty practice, for example, the 2013 China-Tanzania BIT at the preamble encourages investors to respect corporate social responsibilities. ${ }^{200}$ The Brazil's model investment agreement also encourages investors to achieve "the highest possible level of contribution to the sustainable development" and lists "several voluntary principles and standards for a responsible business conduct.",201

\section{Conclusion}

Historically, several attempts were made to establish multilateral investment rules, but all of them failed for some reasons. Today, we are seeing the revival of the interest in establishing multilateral investment rules. The case for a multilateral investment agreement is made in the context of the global backlash against investment arbitration. Although the investment treaty reform has been undertaken at the various levels, some still feel that a multilateral investment agreement is needed as a global effort to address the global backlash. Supporters argue that the current condition may be more favorable than previous, as the interests of developed and developing countries have been progressively converged. In fact, the changing landscape of international investment could be reflected by China's changing outward FDI interest and BIT practice. In recent, China has joined the discussions on and the promotion of multilateral investment rules at the G20 and the WTO. The 2016 G20 Guiding Principles have the potential to serve as a stepping stone for the eventual establishment of multilateral investment rules. However, their general language suggests that the G20 countries may not be able to reach a consensus on some specific investment issues at the current 
stage. The establishment of a multilateral investment agreement is a long process. The investment facilitation, as a less controversial issue, has been successfully advanced at the WTO. The 70 WTO countries have committed to developing a multilateral framework on investment facilitation, but how such a multilateral framework will be crafted remains to be seen. It also remains to be seen what role China will play in this process in the future.

\section{REFERENCES}

1. UNCtaD, World Investment Report 2018: Investment and New Industrial Policies 88 (2018), available at https://unctad.org/en/PublicationsLibrary/wir2018_en.pdf.

2. UNCTAD, World Investment Report 2015: Reforming International Investment Governance 124-5 (2015), available at https://unctad.org/en/PublicationsLibrary/ wir2015_en.pdf.

3. See, e.g., M. Sornarajah, A Coming Crisis: Expansionary Trends in Investment Treaty Arbitration, in Appeals Mechanism in International Investment Disputes (K. Sauvant ed., 2008).

4. See, e.g., M. Waibel el al. eds., The Backlash against Investment Arbitration (2015).

5. 2012 US Model BIT; 2015 Indian Model BIT.

6. UNCTAD, supra note 2, at 169-70.

7. See, e.g., World Economic Forum, Foreign Direct Investment as a Key Driver for Trade, Growth and Prosperity: The Case for a Multilateral Agreement on Investment (2013), available at $\mathrm{http}: / / \mathrm{www} 3$.weforum.org/docs/GAC13/WEF_GAC_GlobalTradeFDI FDIKeyDriver_Report_2013.pdf; A. Aslund, The World Needs a Multilateral Investment Agreement (2013), available at $\mathrm{https} / / / \mathrm{piie} . \mathrm{com} / \mathrm{sites} / \mathrm{default} / \mathrm{files} / \mathrm{publications} / \mathrm{pb} / \mathrm{pb} 13-1$. pdf.

8. See, e.g., A. Berger, Do We Really Need a Multilateral Investment Agreement? (2013), available at https://www.die-gdi.de/uploads/media/BP_9.2013.pdf.

9. UNCTAD, supra note 1, at 4-6.

10. Havana Charter art. 12.

11. G.A. Res/S-6/3201, Declaration on the Establishment of a New International Economic Order (May. 1, 1974); G.A. Res/29/3281 (Charter of Economic Rights and Duties of States) (Dec. 12, 1974).

12. K. Sauvant, The Negotiations of the United Nations Code of Conduct on Transnational Corporations: Experience and Lessons Learned, 16 J. World Inv. \& TRADE 26 (2015). Sauvant noted that it was necessary to distinguish between "legitimate public policy 
objectives, as opposed to other objectives (e.g. protectionist ones)."

13. Id. at 27.

14. Id. at 56-57.

15. UNCTAD, supra note 2, at 123.

16. Sauvant, supra note 12.

17. UNCTAD, supra note 2, at 123.

18. M. Sornarajah, The International Law on Foreign Investment 257 (3d ed. 2010).

19. The Multilateral Agreement on Investment Draft Consolidated Text (Apr. 22, 1998), pmbl.

20. UNCTAD, Lessons from the MAI 23 (1999), available at https://unctad.org/en/Docs/ psiteiitm22.en.pdf.

21. Sornarajah, supra note 18, at 261-2.

22. UNCTAD, supra note 20, at 24.

23. Id. at 18-9. It was required to include a "not lowering" provision - countries do not lower the labor environment and health standards to attract foreign investment.

24. S. Kobrin, The MAI and the Clash of Globalizations, 112 ForeIGn PoL'y 105 (1998).

25. ICTSD, Opposition Building to MAI at WTO (Nov. 9, 1998), available at https://www. ictsd.org/bridges-news/bridges/news/opposition-building-to-mai-at-wto.

26. UNCTAD, supra note 20, at 24-25.

27. Id. at 29 .

28. The four Singapore issues included investment, competition policy, government procurement and trade facilitation. Only trade facilitation remained.

29. World Economic Forum, supra note 7, at 23.

30. C. Xu, Multilateral Investment Agreement and China's Negotiation Strategy in WTO [WTO多边投资协定议题与中国的基本策略分析], 4 L. SCI. [法律科学] 120 (2004). < available only in Chinese>

31. Id.

32. K. Vandevelde, A Comparison of the 2004 and 1994 U.S. Model BITs: Rebalancing Investor and Host Country Interests, in Y.B. InT'L INV. L. \& PoL'y (K. Sauvant ed., 2009).

33. NAFTA Free Trade Commission, Notes of Interpretation of Certain Chapter 11 Provisions (July 31, 2001).

34. Id.

35. Pope \& Talbot Inc. v. The Government of Canada, UNCITRAL, Award on the Merits of Phase 2 (Apr. 10, 2001) at 110.

36. NAFTA, supra note 33; S.D. Myers v Canada (ad hoc arbitration under the 1976 UNCITRAL Rules), Decision (Nov. 12, 2000), at 266.

37. NAFTA, supra note 33.

38. A. Depalma, Nafta's Powerful Little Secrete; Obscure Tribunals Settle Disputes, but Go 
Too Far, Critics Say, N.Y. Times, Mar. 11, 2001. It stated" “Their meetings are secret. Their members are generally unknown. The decisions they reach need not be fully disclosed. Yet the way a small number of international tribunals handles disputes between investors and foreign governments has led to national laws being revoked, justice systems questioned and environmental regulations challenged."

39. Vandevelde, supra note 32.

40. 2004 US Model BIT, annex B.

41. Id. art. 4(b).

42. Id. arts. $12 \& 13$.

43. X. Carim, Lessons from South Africa's BITs Review, 109 Colum. FDI Perspectives (2013).

44. Churchill Mining v. Indonesia, ICSID Case No. ARB/12/14 and 12/40, Award (Dec. 6, 2016). Indonesia is considering renegotiating the IIAs based on a modern template.

45. Australia has changed its attitude towards the investor-state dispute settlement to "caseby-case." The recent China-Australia FTA provides foreign investors with access to international arbitration.

46. Philip Morris v. Australia, UNCITRAL, PCA Case No. 2012-12, Award on Jurisdiction and Admissibility (Dec. 17, 2015).

47. See e.g., N. Bernasconi-Osterwalder, Giving Arbitrators carte blanche - Fair and Equitable Treatment in Investment Treaties, in Alternative Visions of the InTERnATIONAL Law on Foreign Investment: Essays in honour of Muthucumaraswamy Sornarajah (C. Lim ed., 2016) (expansive interpretations of the FET standard by tribunals).

48. See e.g., S. Franck \& L. Wiley, Predicting Outcomes in Investment Treaty Arbitration, 65 DuKe L. J. (2015).

49. C. Brower \& S. Schill, Is Arbitration a Threat or a Boon to the Legitimacy of International Investment Law?, 9 CHI. J. INT'L L.475 (2009).

50. Waibel, supra note 4, at 2-5.

51. Id.

52. J. Yackee, Do BITs Really Work? Revisiting the Empirical Link between Investment Treaties and Foreign Direct Investment, in The Effect of Treaties on Foreign Direct Investment: Bilateral Investment Treaties, Double Taxation Treaties and Investment FLows (K. Sauvant \& L. Sachs eds., 2009).

53. S. Schill, $W(h)$ ither Fragmentation? On the Literature and Sociology of International Investment Law, 22 Euro J. InT'L L. 898-9 (2011).

54. See e.g. M. Kantor, Little Has Changed in the New US Model Bilateral Investment Agreements, 27 ICSID REv. 335 (2012).

55. For details, see the Special Issue of the Journal of World Investment \& Trade: The Anatomy of the (Invisible) EU Model BIT 15 (15:3-4 JWIT 2014).

56. 2015 Indian Model BIT; White Industries Australia Limited v. The Republic of India, (ad 
hoc arbitration under UNCTRAL), Final Award (Nov. 30, 2011).

57. China-India BIT (2006) Protocol ad art. 5.

58. UNCTAD, supra note 2, at 164-7.

59. Id. at 167-168.

60. Id.

61. M. Feldman el al., The Role of Pacific Rim FTAs in the Harmonisation of International Investment Law: Towards a Free Trade Area of the Asia-Pacific (Mar. 2016), available at http://e15initiative.org/wp-content/uploads/2015/09/E15-Investment-FeldmanMonardes-Rodriguez-Chiffelle-Final.pdf.

62. It has been asked whether there is regionalism in international investment rulemaking. For details on the investment treaty practices in the EU, Asia, Latin America and Africa, see 15:3-4 J. World Inv. \& Trade (2014); 16: 5-6 J. World Inv. \& Trade (2015); 17: 4 J. World Inv. \& TRAde (2016); 18: 3 J. World Inv. \& TRAde (2017), respectively.

63. K. Sauvant \& F. Ortino, Improving the International Investment Law and Policy Regime: Options for the Future (2013), at 126-7, available at http://ccsi.columbia. edu/files/2014/03/Improving-The-International-Investment-Law-and-Policy-RegimeOptions-for-the-Future-Sept-2013.pdf.

64. Id.

65. UNCTAD, supra note 2, at 169-70.

66. World Economic Forum, supra note 7; Aslund, supra note 7; Justin Yifu Lin, China's G-20 Agenda: Call for a Multilateral Investment Framework for Development (July 2015), available at http://e15initiative.org/blogs/chinas-g-20-agenda-call-for-amultilateral-investment-framework-for-development; W. Shan, Toward a Multilateral or Plurilateral Framework on Investment (Nov. 2015), available at http://e15initiative.org/ publications/toward-a-multilateral-or-plurilateral-framework-on-investment.

67. Id. Shan at 2-3; Lin at 1-2.

68. The statistics was from the UNCTAD database, available at https://unctad.org/en/Pages/ DIAE/FDI\%20Statistics/FDI-Statistics.aspx.

69. Id.

70. Shan, supra note 66, at 2.

71. Id.

72. K. Sauvant, China Moves the G20 toward an International Investment Framework and Investment Facilitation, in China's Three-Prong Investment Strategy: Bilateral, Regional, and Global Tracks (J. Chaisse ed., 2018).

73. Shan, supra note 66 , at 3.

74. Sauvant, supra note 72.

75. UNCTAD, supra note 2, at 169-70.

76. Berger, supra note 8; S. Donnelly, Let's Get Realistic about a Multilateral Investment Agreement (2016), available at https://www.uscib.org/lets-get-realistic-about-a- 
multilateral-investment-agreement.

77. World Economic Forum, supra note 7, at 31; Aslund, supra note 7, at 7; Sauvant \& Ortino, supra note 63, at 127-30; Shan, supra note 66, at 12; Lin, supra note 66, at 2.

78. World Economic Forum, supra note 7, at 31; Aslund, supra note 7, at 7.

79. Aslund, supra note 7, at 7.

80. Shan, supra note 66, at 12.

81. Id.

82. Id. 12-13; Sauvant and Ortino supra note 63, at 130-7.

83. China-Sweden BIT (1982).

84. W. Shan \& N. Gallagher, Chinese Investment Treaties: Policies And Practice 1.661.67 (2009).

85. Id. Shan and Gallagher classified Chinese investment treaties into three generations: the first generation (1982-1989); the second generation (1990-1997); and the third generation (1998-present).

86. See, e.g., China-Peru BIT (1994) art 8.

87. The narrow reading was adopted by the tribunals of Berschader v. The Russian Federation and RosInvest UK Ltd. v. The Russian Federation, while the broad reading was adopted in Saipem S.p.A v. Bangladesh and Telenor Mobile Communications A.S. v. Hungary.

88. Tza Yap Shum v. Republic of Peru, ICSID Case No. ARB/07/6, Decision on Jurisdiction and Competence (Jan. 19, 2009); Sanum Investments Limited v. People's Democratic Republic, UNCITRAL, PCA Case No 2013-13, Award on Jurisdiction (Dec. 13, 2013); Government of the Lao People's Democratic Republic v. Sanum Investments Limited [2015] SGHC 15; Sanum Investments Limited v. the Government of the Lao People's Democratic Republic [2016] SGCA 57.

89. See, e.g., the first version of Chinese Model BIT; the second version of Chinese Model BIT, art.3.

90. Sino-Foreign Equity Joint Venture Law (1979); Sino-Foreign Contractual Joint Venture Law (1988); and the Wholly Foreign Owned Enterprises Law (1986). Three laws were subsequently revised several times.

91. Catalogue for the Guidance of Foreign Investment Industries (1995). The catalogue was revised several times, as well.

92. Sauvant, supra note 12, at 22.

93. See, e.g., China-Germany BIT (2003), art.9.

94. G. Wang, Investor-State Dispute Settlement in China, 5 Transnat'l Disp. Settlement 12 (2011).

95. See, e.g., the third version of Chinese Model BIT, art.3; China-Germany BIT (2003), art.3.

96. This could be mainly attributed to China's accession to the WTO in 2001.

97. S. Schill, Tearing Down the Great Wall: The New Generation Investment Treaties of the 
People's Republic of China, 15 CARDOzo J. InT'L. \& Comp. L. 73 (2007).

98. Id.

99. Shan \& Gallagher, supra note 84, 1.79.

100. See generally W. Shan, N. Gallagher \& S. Zhang, National Treatment for Foreign Investment in China: A Changing Landscape, 27 ICSID Rev. (2012).

101. H. Chen, OeCD’s Multilateral Agreement on Investment: A Chinese Perspective, the conclusion chapter (2002).

102. $\mathrm{Xu}$, supra note 30 . (conclusion chapter)

103. Id. See also World Economic Forum, supra note 7 at 23.

104. Id.

105. The statistics was from the UNCTAD database, available at https://unctad.org/en/Pages/ DIAE/FDI\%20Statistics/FDI-Statistics.aspx.

106. Id.

107. UNCTAD, supra note 1.

108. At the 2013 Strategic and Economic Dialogue, China and the US recognized that the BIT would "provide national treatment at all phases of investment, including market access ('pre-establishment'), and be negotiated under a 'negative list' approach," available at $\mathrm{https} / / / \mathrm{www}$.treasury.gov/press-center/press-releases/Pages/j12010.aspx.

109. J. Huang, Challenges and Solutions for the China-US BIT Negotiations: Insights from the Recent Development of FTZs in China, 18 J. INT'L ECon. L. (2015).

110. New Foreign Investment Law (Mar. 2019). For details, see generally S. Chong and C. L. Lim, The Convergence of China's Foreign and Domestic Investment Regimes and China's Investment Treaty Commitments, 32 J. InT'L ARB. (2015).

111. New Foreign Investment Law, art 4.

112. 2017 version of the Catalogue for the Guidance of Foreign Investment Industries.

113. 2018 version of the Catalogue for the Guidance of Foreign Investment Industries.

114. See e.g., E. Dulac, The Emerging Third Generation of Chinese Investment Treaties, 4 Transnat'l Disp. Settlement (2010).

115. See e.g. China-Canada BIT (2012), art.4; China-Korea-Japan investment agreement (2012), art. 5.

116. China-Canada BIT (2012), annex B.

117. Id. art. 33.

118. Id. pt. C.

119. Id. art. 28.

120. W. Shan \& H. Chen, China-US BIT Negotiation and the Emerging Chinese BIT 4.0, in Lim, supra note 47.

121. Id.

122. Id.

123. See, e.g., C. Cai, China-US Negotiations and the Future of Investment Treaty Regime: A 
Grand Bilateral Bargain with Multilateral Implications, 12(2) J. InT'L Econ. L. (2009); K. Sauvant \& H. Chen, A China-US Bilateral Investment Treaty: A Template for a Multilateral Framework for Investment?, 85 Colum. FDI PerspeCtives (2012).

124. Shan, supra note 66; Lin, supra note 66.

125. 2016 G20 Trade Ministers Meeting Statement (released 10 July 2016), annex I.

126. Sauvant, supra note 72 , at 11.

127. G20 Guiding Principles for Global Investment Policymaking (Sept. 4-5, 2016). [hereinafter G20 Guiding Principles]. The first draft of the guiding principles was based on the UNCTAD Investment Policy Framework for Sustainable Development.

128. Id.

129. Id.

130. J. Zhan, G20 Guiding Principles for Global Investment Policymaking: A Facilitator's Perspective (Dec. 2016), at 3, available at http://e15initiative.org/wp-content/ uploads/2015/09/E15-Investment-Zhan-Final-1.pdf.

131. Id.

132. G20 Guiding Principle, princ. III.

133. Zhan, supra note 130, at 5; A. Joubin-Bret \& C. Chiffelle, G20 Guiding Principles for Global Investment Policy-Making: A Stepping Stone for Multilateral Rules on Investment (Jan. 2017), at 8, available at http://e15initiative.org/publications/ g20-guiding-principles-for-global-investment-policymaking-a-stepping-stone-formultilateral-rules-on-investment.

134. Id.

135. Zhan, supra note 130, at 5.

136. 2012 US Model BIT, art. 5.

137. Id.

138. A. Berger, Hesitant Embrace: China's Recent Approach to International Investment Rule-Making, 16 J. World Inv. \& Trade (2015).

139. CETA, art. 8.10.

140. Bernasconi-Osterwalder, supra note 47.

141. 2012 US Model BIT, Sec B.

142. A. Roberts, The Shifting Landscape of Investor-State Arbitration: Loyalists, Reformists, Revolutionaries and Undecideds (2017), available at https://www.ejiltalk.org/theshifting-landscape-of-investor-state-arbitration-loyalists-reformists-revolutionaries-andundecideds.

143. Id.

144. $I d$.

145. 2015 Indian Model BIT.

146. Brazil's Model investment agreement.

147. South Africa's Protection of Investment Act No. 22 (2015). 
148. G20 Guiding Principle, princ. VI.

149. 2012 US Model BIT, pmbl.

150. 2015 Indian Model BIT, pmbl.

151. CETA, art. 8.9.

152. Zhan, supra note 130, at. 5.

153. CETA, pmbl.; China-Canada BIT (2012), art. 33.

154. X. Zhan, A Path to New Global Investment Governance: Implications of the G20 Guiding Principles for Global Investment Policymaking [全球投资治理新路径一解读 《G20全球投资政策指导原则》], 10 WorLd ECON. \& Politics [世界政治与经济] 8 (2016). $<$ available only in Chinese $>$

155. Id.

156. Id.

157. Sauvant, supra note 72.

158. After the 2016 G20, it was suggested that the implementation of the G20 Guiding Principles should be promoted. See Zhan, supra note 154, at 15-6; Joubin-Bret and Chiffelle also noted: "It will be left to the implementation and the follow-up to show whether the focus is on setting a stepping stone for investment negotiations, or carefully circling around any kind of international investment rules." See Joubin-Bret \& Chiffelle, supra note 133, at 10. For the IIAs of the G20 countries and the Guiding Principles, see R. Polanco Lazo, G20 International Investment Agreements and Guiding Principles for Global Investment Policymaking (Nov. 2017), available at http://e15initiative.org/ publications/g20-international-investment-agreements-and-guiding-principles-forglobal-investment-policymaking.

159. Sauvant, supra note 72.

160. Id.

161. Zhan, supra note 154 .

162. 2016 G20 Trade Ministers Meeting Statement (July 10, 2016).

163. A. Berger, What's Next for the Investment Facilitation Agenda?, 224 Colum. FDI Perspectives (2018).

164. See, e.g., UNCTAD Global Action Menu for Investment Facilitation.

165. Lin, supra note 66.

166. Sauvant, supra note 72.

167. Proposal for a WTO Informal Dialogue on Investment Facilitation for Development: Joint Communication from the Friends of Investment Facilitation for Development (Apr. 21, 2017) (Job/GC/122 and Job/GC/122/ADD.1). [hereinafter Joint Communication for the FIFD].

168. WTO, Investment Facilitation: Relationship Between Trade and Investment, available at https://www.wto.org/english/thewto_e/minist_e/mc11_e/briefing_notes_e/bfinvestfac_ e.htm. 
169. Communication from the Russian Federation (Job/GC/120); Communication from China (Job/GC/123); Communication from the Argentina and Brazil (Job/GC/124).

170. R. Joseph, Investment Facilitation: New Dynamism at the WTO on Investment, 235 Colum. FDI Perspectives (2018).

171. WTO, supra note 168.

172. Id.

173. This dialogue was opposed by some developing countries, such as India. It is worth mentioning that in August 2017 the BRICS summit under China's presidency approved the Outlines for BRICs Investment Facilitation.

174. Joseph, supra note 170.

175. Joint Communication for the FIFD.

176. UNCTAD, supra note 1 , at 6.

177. Joseph, supra note 170.

178. WTO, supra note 168.

179. X. Zhang, Statement of Ambassador ZHANG Xiangchen at the Informal Dialogue on Investment Facilitation for Development [为什么投资便利化问题需要在多边讨论-张向晨 大使在投资便利化非正式对话上的讲话] (May 24, 2017).

180. Id.

181. Joint Ministerial Statement on Investment Facilitation for Development (Dec. 13, 2017) [hereinafter Joint Statement on Investment Facilitation].

182. Structured Discussions on Investment Facilitation: Communication from Brazil (Jan. 31, 2018).

183. Berger supra note 163.

184. Joint Statement on Investment Facilitation.

185. Id.

186. Id.

187. Communication from China (Job/GC/123).

188. Id.

189. The comment opportunities are not addressed in the Russia's proposal.

190. 2012 US Model BIT, art. 11.

191. Huang, supra note 109.

192. Communication from China (Job/GC/123).

193. Id.

194. Id.

195. Communication from the Argentina and Brazil (Job/GC/124).

196. Structured Discussions on Investment Facilitation: Communication from Brazil, art. 9.

197. Id.

198. The corporate responsibility is not addressed in Russia's proposal.

199. G20 Guiding Principles, princ. VIII. 
200. China-Tanzania BIT (2013).

201. Brazil's Model Investment Agreement. 